\title{
ANALISIS KETERAMPILAN METAKOGNITIF SISWA DALAM MEMAHAMI PELAJARAN MATEMATIKA
}

\author{
Oleh : \\ Norli Trimawanti Purba ${ }^{1}$, Nunik Ardiana ${ }^{2}$, Sinar Depi Harahap ${ }^{3}$ \\ Fakultas MIPA Program Studi Pendidikan Matematika \\ Institut Pendidikan Tapanuli Selatan
}

\begin{abstract}
Abstrak
Penelitian ini bertujuan untuk menganalisis kemampuan metakognitif siswa dalam memahami mata pelajaran matematika di SMP Negeri 3 Satu Atap Andam Dewi. Pendekatan penelitian ini adalah deskriptif kualitatif. Subyek penelitian terdiri dari 6 siswa. Observasi, tes, dan wawancara digunakan dalam pengumpulan data dan teknik triangulasi digunakan dalam teknik analisis. Hasil penelitian menunjukkan rata-rata kemampuan metakognitif siswa adalah 71,325 (kategori sedang). Artinya, metakognitif siswa dalam memahami pelajaran matematika meliputi siswa memiliki kemampuan dalam melakukan perencanaan, pemantauan dalam memecahkan masalah, dan memberikan penilian dengan melihat kembali.
\end{abstract}

Kata kunci: keterampilan metakognitif, pelajaran matematika

\begin{abstract}
The aim of the research is to analyze students' metacognitive skill in understanding mathematics subject in SMP Negeri 3 Satu Atap Andam Dewi. The approach of the research is descriptive qualitative. Subject of the research consist of 6 students. Observation, test, and interview were used in collecting the data and triangulation technique was used in analysis technique. The research of the research shows the average of students' metacognitive skill is 71.325 (medium category). It means, students metacognitive in understanding mathematics subject include students have ability in conducting planning, monitoring in solving the problem, and giving the score by looking back.
\end{abstract}

Keywords: metacognitive skil, mathematics subject

\section{PENDAHULUAN}

Pendidikan merupakan serangkaian proses menuju kedewasaan baik kedewasaan berpikir, berucap, maupun bertingkah laku. Di indonesia pendidikan diatur dalam Undang-undang tersendiri mengenai Sistem Pendidikan Nasional (Sisdiknas). Seperti yang tercantum dalam Undang-undang Sisdiknas tahun 2003 bahwa, "Pendidikan nasional berfungsi mengembangkan kemampuan dan membentuk watak serta peradaban bangsa yang bermartabat dalam rangka mencerdaskan kehidupan bangsa, bertujuan untuk berkembangnya potensi peserta didik agar menjadi manusia yang beriman, dan bertaqwa kepada Tuhan Yang Maha Esa, berahlak mulia, sehat berilmu, cakap, kreatif mandiri, dan menjadi warga Negara yang demokratis serta bertanggung jawab". Perwujutan fungsi dan tujuan pendidikan tersebut dapat dimulai dengan memperbaiki proses pembelajaran disekolah.

Matematika merupakan salah satu mata pelajaran yang diajarkan disetiap jenjang sekolah, baik tingkat sekolah dasar, menengah maupun perguruan tinggi. Dalam pembelajaran matematika siswa dilatih serta diajarkan berpikir logis, rasional, kritis, dan mengetahui sejauh mana konsep yang diperoleh siswa. Depdiknas (2006) menyatakan bahwa pembelajaran matematika disekolah memiliki empat tujuan utama, (1)melatih cara berpikir dan bernalar dalam menarik kesimpulan, (2)Mengembangkan aktivitas kreatif yang melibatkan imajinasi intuisi dan penemuan dengan mengembangkan kemampuan divergen, (3)Mengembangkan kemampuan pemecahan masalah, (4)dan mengembangkan kemampuan menyampaikan informasi dan mengkomunikasikan gagasan. Sehingga dari tujuan-tujuan tersebut, dalam pembelajaran matematika adalah mengajak siswa untuk melatih dan mengasah pola pikirnya.

Keterampilan merupakan suatu kemampuan dalam menggunakan akal, fikiran, ide serta kreativitas dalam mengerjakan, mengubah atau juga membuat sesuatu itu jadi bermakna sehingga dari hal tersebut menghasilkan sebuah nilai dari hasil pekerjaan tersebut. Maka dapat diartikan keterampilan metakognitif adalah kemampuan seseorang tentang proses dan cara berpikir pada hal-hal yang dilakukan sehingga meningkatkan proses belajar dan memori.

Selanjutnya metakognitif adalah suatu kata yang berkaitan dengan apa yang dia ketahui tentang dirinya sebagai individu yang belajar dan bagaimana dia mengontrol serta menyesuaikan perilakunya 
Suherman dalam (Kartika, 2015:1022). Menurut Schraw dan Ronning dalam (Anggo, 2011:36) secara umum metakognitif berkaitan dengan dua dimensi berpikir yaitu (1) Self-awareness of cognition, yaitu pengetahuan yang dimiliki seseorang tentang berpikirnya sendiri dan (2) Self-regulation of cognitif, yaitu kemampuan seseorang menggunakan kesadaran untuk mengatur proses kognitifnya sendiri.

Sehingga dapat disimpulkan bahwa keterampilan metakognitif adalah kesadaran tau pengetahuan seseorang terhadap proses dan hasil berpikirnya serta kemampuannya dalam mengontrol dan mengevaluasi proses berpikirnya tersebut. Jacob \& Paris (Gredler, 2011:276) "metakognitif terdiri dari tiga komponen yaitu perencanaan, monitoring, dan evaluasi". Menurut Taccasu dalam (Arum, 2017:25) mendefenisikan "Metakognitif yaitu bagian dari perencanaan, pemonitoringan, dam pengevaluasian proses belajar serta kesadaran dan pengontrolan proses belajar". Sejalan dengan pemikiran tersebut, Kaune dalam (Arum, 2017:25) menyimpulkan bahwa "kemampuan metakognitif merupakan kemampuan yang melihat kembali proses berpikir yang dilakukan seseorang, metakognitif terdiri dari tiga elemen planning, monitoring, dan evaluation".

Selanjutnya, North Central Regional Education Laborarory (NCREL) (Arum, 2017:25-26) mengemukakan bahwa secara umum metakognitif terdiri dari tiga elemen dasar, yaitu: (1) Developing $e$ plan of action (mengembangkan rencana tindakan) (2) Maintaining/monitoring the plan (memonitor rencana tindakan). Sehingga dalam penelitian ini sesuai dengan beberapa pendapat para ahli di atas komponen-komponen keterampilan metakognitif yaitu melakukan perencanaan, pemantauan, dan evaluasi.

\section{METODE PENELITIAN}

Metode kualitatif adalah penelitian yang menghasilkan data deskriftif atau hanya mengambil gambarannya. Menurut Bogdan dan Taylor dalam Ahmad (2014:18) mengemukakan "Metode kualitatif sebagai prosedur penelitian yang menghasilkan data deskriftif berupa kata-kata atau lisan dari orangorang dan perilaku yang dapat diamati". Menurut Sugiyono (2018:15) mengatakan "Metode penelitian kualitatif adalah metode penelitian yang berlandaskan pada filsafat postpositivisme, digunakan untuk meneliti pada kondisi obyek yang alamiah, (sebagai lawannya adalah eksperimen) dimana peneliti adalah sebagai instrumen kunci, pengambilan sampel sebagai sumber data dilakukan secara purposive dan snowbal, teknik pengumpulan data (gabungan), analisis data bersifat induktif/kualitatif, dan hasil penelitian kualitatif lebih menekankan makna dari pada generalisasi.

dalam penelitian itu yaitu siswa/siswa kelas VIII-b dan Guru mata pelajaran matematika yang berada di SMP Negeri 3 Satu Atap Andam Dewi.

Teknik pengumpulan data merupakan langkah atau cara mengumpulan data dengan tujuan mendapatkan data yang lebih valid. Dalam penelitian kualitatif, pengumpulan data dilakukan pada natural setting (kondisi yang alamiah), sumber data primer, dan teknik pengumpulan data lebih banyak pada observasi berperanserta (partisipation observation), wawancara mendalam (in depth intereview), dan Tes. Adapun pedoman penilaian didasarkan pedoman penskoran rubrik untuk keterampilan metakognitif siswa dalam memahami pelajaran matematika yang dimodifikasi dari sumarto (1994), sebagai berikut :

Tabel 1. Pendoman Penskoran Rubrik Tes Keterampilan Metakognitif Siswa Dalam Memahami Pelajaran Matematika

\begin{tabular}{|c|c|c|c|}
\hline Aspek yang di & lai & Reaksi terhadap soal & Skor \\
\hline \multirow{8}{*}{ Perencanaan } & \multirow{4}{*}{$\begin{array}{l}\text { Memahami } \\
\text { Masalah }\end{array}$} & Tidak memahami masalah & 1 \\
\hline & & Kurang memahami masalah & 2 \\
\hline & & Cukup memahami masalah & 3 \\
\hline & & Mampu memahami masalah & 4 \\
\hline & \multirow{4}{*}{$\begin{array}{l}\text { Merancang } \\
\text { Rencana }\end{array}$} & Tidak mampu merancang rencana & 1 \\
\hline & & Mampu merancang rencana, tetapi tidak tepat & 2 \\
\hline & & Cukup mampu merancang rencana & 3 \\
\hline & & Mampu merancang rencana & 4 \\
\hline \multirow{3}{*}{ Pemantauan } & \multirow{3}{*}{$\begin{array}{l}\text { Melaksanakan } \\
\text { rencana }\end{array}$} & $\begin{array}{l}\text { Tidak mampu melaksanakan pemecahan } \\
\text { masalah }\end{array}$ & 1 \\
\hline & & $\begin{array}{l}\text { Mampu melaksanakan pemecahan masalah, } \\
\text { tetapi tidak tepat }\end{array}$ & 2 \\
\hline & & $\begin{array}{l}\text { Cukup mampu melaksanakan pemecahan } \\
\text { masalah }\end{array}$ & 3 \\
\hline
\end{tabular}


ISSN. 2621-9832

JURNAL MathEdu (Mathematic Education Journal) http://journal.ipts.ac.id/index.php/MathEdu Vol. 4 . No. 3 November 2021

\begin{tabular}{|c|c|c|c|}
\hline & & Mampu melaksanakan pemecahan masalah & 4 \\
\hline \multirow{4}{*}{ Evaluasi } & \multirow{4}{*}{$\begin{array}{l}\text { Melihat } \\
\text { kembali }\end{array}$} & $\begin{array}{l}\text { Tidak mampu membuat langkah memeriksa } \\
\text { kembali solusi }\end{array}$ & 1 \\
\hline & & $\begin{array}{l}\text { Membuat langkah memeriksa kembali solusi, } \\
\text { tetapi tidak tepat }\end{array}$ & 2 \\
\hline & & $\begin{array}{l}\text { Cukup mampu membuat langkah memeriksa } \\
\text { kembali solusi }\end{array}$ & 3 \\
\hline & & $\begin{array}{l}\text { Mampu membuat langkah memeriksa kembali } \\
\text { solusi }\end{array}$ & 4 \\
\hline
\end{tabular}

Dalam penelitian kualitatif peneliti mengungkapkan kebenaran obyektif, oleh karena itu keabsahan data dalam penelitian kualitatif sangat penting. Hal ini bertujuan untuk mengukur tingkat kepercayaan (kredibilitas) penelitian kualitatif sehingga dapat dipertanggungjawabkan secara ilmiah. Pengukuran keabsahan data dalam penelitian ini menggunakan triangulasi.

Triangulasi menyatukan informasi dari penelitian kuantitatif dan kualitatif, Menurut Rangkuti (2014: 146) "Triangulasi adalah pendekatan analisis data yang mensintesis data dari berbagai sumber". Apakah analisis dari sumber yang berbeda. Menurut Stainback dalam Sugiyono 2007: 330 dalam Rangkuti (2014: 146) "Triangulasi bukan bertujuan untuk menemukan, tetapi meningkatkan pemahaman peneliti terhadap data dan fakta yang dimilikinya". Triangulasi bukan untuk menemukan kebenaran tetapi untuk meningkatkan peneliti pengetahuan. Menurut Wiliam Wiersma dalam Sugiyono 2007: 372 dalam Rangkuti (2014: 146) "Triangulasi adalah cara memperoleh data yang benar-benar valid dengan menggunakan beberapa metode". Adalah cara untuk mendapatkan data dengan berbagai metode.

Teknik analisis data penelitian kualitatif, data diperoleh dari berbagai sumber,Menurut Rangkuti (2014: 154) "Analisis data adalah proses pencarian dan penyusunan secara sistematis transkrip wawancara, catatan lapangan dan akumulasi materi lainnya untuk meningkatkan pemahaman peneliti tentang apa yang mereka capai". Merupakan data dari lapangan untuk meningkatkan pemahaman peneliti terhadap apa yang diteliti. Menurut Bogdan dalam Sugiyono (2017: 334) "Analisis data adalah proses mencari dan menyusun secara sistematis transkrip wawancara, catatan lapangan, dan materi lain yang Anda kumpulkan untuk meningkatkan pemahaman Anda sendiri tentang mereka dan memungkinkan Anda untuk mempresentasikan apa yang anda miliki. ditemukan kepada orang lain ". Jadi analisis data merupakan cara sistematis dari semua proses yang telah dilakukan sebelumnya.

Sedangkan Menurut Stainback dalam Sugiyono (2017: 335) "Analisis data sangat penting untuk proses penelitian kualitatif. Ini adalah pengakuan, studi dan pemahaman tentang keterkaitan dan konsep dalam hipotesis dan pernyataan data Anda yang dapat dikembangkan dan dievaluasi ". Analisis data digunakan untuk memahami konsep data, sehingga hipotesis dapat dievaluasi.

1. Reduksi Data

Reduksi data merupakan proses berpikir sensitif yang membutuhkan kecerdasan dan keluasan serta wawasan yang mendalam. Menurut Sugiyono (2017: 338) "Pengurangan Data artinya meringkas, memilih yang utama, fokus pada hal yang penting, melihat tema dan pola serta menghilangkan yang tidak penting". Jadi reduksi data fokus pada hal yang penting. Menurut Rangkuti (2014: 156) "Reduksi data artinya meringkas, memilih hal-hal utama, memfokuskan pada hal-hal yang penting untuk dicari tema dan pola serta menghilangkan yang tidak perlu". Senada dengan Sugiyono Rangkuti mengatakan reduksi data hanya fokus pada hal yang penting.

2. Penyajian Data

Setelah data direduksi maka langkah selanjutnya adalah membuat tampilan data. Menurut Rangkuti (2014: 157) "Tampilan data juga diartikan sebagai data yang terorganisir, suatu cara memampatkan informasi yang memungkinkan suatu kesimpulan atau tindakan diambil sebagai bagian dari analisis". Tampilan data merupakan kemungkinan tindakan yang dilakukan peneliti sebagai bagian dari analisis.

Dalam hal ini Miles \& Huberman dalam Sugiyono (2017: 341) "Dengan menampilkan data maka akan lebih mudah untuk memahami apa yang terjadi, merencanakan pekerjaan selanjutnya berdasarkan apa yang telah dipahami". Tampilan data digunakan untuk memahami apa yang terjadi dengan apa yang terjadi sebelumnya. "Data yang paling sering ditampilkan untuk data penelitian kualitatif adalah teks naratif". Tampilan data dalam penelitian kualitatif adalah teks naratif. Berdasarkan uraian pakar di atas, peneliti menyimpulkan penyajian data merupakan suatu kegiatan dalam penelitian yang dilakukan untuk memudahkan dan memahami informasi yang dianalisis. 
3. Kesimpulan/ Verifikasi

Langkah selanjutnya dalam menganalisis data dalam penelitian kualitatif adalah penarikan kesimpulan dan verifikasi. Menurut Miles \& Huberman dalam Rangkuti (2014: 158) "Kesimpulan dan verifikasi adalah kesimpulan awal yang bersifat sementara dan akan berubah jika ditemukan bukti kuat untuk mendukungnya pada tahap data selanjutnya". Apakah kesimpulan dapat berubah jika peneliti menemukan kesimpulan lain.

Menurut Sugiyono (2017: 345) "Kesimpulan yang diharapkan dalam penelitian kualitatif adalah temuan baru yang belum pernah ada sebelumnya. Temuan deskripsi benda yang tadinya redup atau gelap sehingga setelah diteliti menjadi jelas ". Jadi kesimpulan itu berarti membuat kesimpulan yang jelas. Menurut Rangkuti (2014: 158) "Kesimpulan dan verifikasi data adalah tindakan penelitian dalam menginterpretasikan data yang mendeskripsikan kekuatan tampilan". Merupakan tindakan dari peneliti untuk menginterpretasikan tampilan data.

\section{HASIL DAN PEMBAHASAN}

Hasil penelitian yang disajikan dalam bentuk analisis keterampilan metakognitif siswa dalam memahami pelajaran matematika.

\section{Pembahasan hasil jawaban soal tes}

Soal tes ini dilaksanakan pada tanggal 26 April 2021 informan dalan penelitian ini sebanyak 6 orang siswa di SMP Negeri 3 Satu Atap Andam Dewi.

Tabel 2

Kriteria Penilaian sial tes keterampilan matematika siswa

\begin{tabular}{cccc}
\hline No & Inisial Siswa & Nilai & Kategori \\
\hline 1 & AGTS & 100 & Sangat Tinggi \\
\hline 2 & CAMS & 87,5 & Tinggi \\
\hline 3 & HLM & 76,5 & Sedang \\
\hline 4 & IOH & 46,8 & Rendah \\
\hline 5 & LT & 73,4 & Sedang \\
\hline 6 & RRH & 43,75 & Rendah \\
\hline & & $\frac{427,95}{6}=71,325$ & Sedang \\
\hline
\end{tabular}

Pada bagian ini akan dipaparkan oleh peneliti mengenai data-data yang berkenaan dalam proses penelitian dan subjek penelitian. Peneliti menganalisis jawaban siswa yang mengacu pada petunjuk soal dan ketepatan siswa dalam menjawab dimana ketepatan jawaban siswa tersebut berdasarkan pada standar indikator keterampilan metakognitif siswa. Selanjutnya dari hasil analisis peneliti terhadap respon hasil jawaban siswa, peneliti menemukan siswa yang menjadi subjek wawancara agar memperoleh dan memperkuat data yang lebih valid dari yang telah dikerjakan siswa. Berdasarkan tabel 4.1 di atas dapat dilihat bahwa minat belajar matematika siswa di SMP Negeri 3 Satu Atap Andam Dewi kelas VIII-B dengan rata-rata 71,325 yakni pada kategori "Sedang". Berdasarkan hasil yang telah di analisis peneliti dari 3 yang menjadi subjek penelitian yaitu siswa AGST, HLM, IOH. Yakni siswa AGST yang memiliki keterampilan metakognitif yang tinggi. Siswa HLM memiliki keterampilan metakognitif sedang yaitu dalam kemampuan tidak terlalu tinggi dan siswa IOH yang memiliki keterampilan metakognitif yang rendah.

\section{KESIMPULAN}

\section{A. Kesimpulan}

Berdasarkan hasil penelitian yang dilaksanakan, penulis menarik kesimpulan yang didasarkan pada analisis data dan pembahasan. Adapun kesimpulan tersebut sebagai berikut:

1. Siswa yang berkemampuan tinggi dalam memahami pelajaran matematika akan memiliki keterampilan metakognitif "Sangat Baik" artinya dengan memiliki keterampilan metakognitif "Sangat Baik", siswa secara signifikan memiliki kemampuan memahami pelajaran matematika dengan nilai tinggi.

2. Siswa yang berkemampuan sedang dalam memahami pelajaran matematika akan memiliki keterampilan metakognitif "Baik" artinya dengan memiliki keterampilan metakognitif 
"Baik", siswa secara signifikan memiliki kemampuan memahami pelajaran matematika dengan nilai sedang.

Siswa yang berkemampuan rendah dalam memahami pelajaran matematika akan memiliki keterampilan metakognitif "Cukup" artinya dengan memiliki keterampilan metakognitif "Cukup", siswa secara signifikan memiliki kemampuan memahami pelajaran matematika dengan nilai rendah.

\section{B. Saran}

Berdasarkan hasil penelitian, penulis menyarankan hal-hal sebagai berikut:

1. Bagi Siswa, diharapkan agar lebih aktif dan giat belajar terutama latihan-latihan menyelesaian soal matematika guna mencapai keterampilan metakognitif yang baik.

2. Kepada Guru, hendaknya lebih cermat dan memilih atau menentukan cara mengajar siswa. Dimana guru harus mampu membedakan tingkat kemampuan antara siswa yang satu dengan siswa yang lain. selanjutnya, guru hendak selalu mengarahkan siswa untuk menggunakan langkah-langkah menyelesaikan pelajaran matematika guna menciptakan keterampilan metakognitif siswa kearah yang lebih baik.

3. Kepada Kepala Sekolah, selaku Pembina instansi diharapkan dapat meningkatkan dan memberikan masukan kepada guru kelas untuk lebih meningkatkan kemampuan belajar dan memberikan penataran-penataran khususnya pada mata pelajaran matematika.

4. Kepada rekan-rekan mahasiswa dan para peneliti, ada kemungkinan kelemahan yang terjadi dalam pelaksanaan penelitian ini, maka perlu kiranya diadakan penelitian lebih lanjut.

\section{REFERENSI}

Al-Gaseem, Mohammad, Bakkar-bakkar dan Suhail Al-zoubi. 2020. Metacognitive Thinking Skills Among Talented Science Education Student. Journal For The Education Of Gifred.Vol.8.No.1

Amin Ihdi. 2015. Analisis Metacognitive Skills On Learning Mathematics Higs School. Internasional Journal of Educations and Researcs. Vol.3. No3

Bakkaloglu, Selva. 2020. Analysis Of Metakognitive Awareness Of Primary And Secondary School Students In Terms Of Some Variables. Journal Of Education and Learning. Vol.9.No.1

Darmawan, Erikca, Dkk. 2020. Simas Eric Learning Model (SELM): Enhance Student Metacognitive Skill Based On The Academic Level. Internasional Journal Of Instruction. Vol.13.No.4

Fitrih, Diah Maya, Nunik Ardiana dan Yulia Pratiwi. 2018. Analisis Keterampilan Metakognitif Ditinjau Dari Kemampuan Pemecahan Masalah Siswa Kelas XI MAN Panyabungan. JURNAL Mathedu (Matematic Education Journal). Vol. 1. No.1

Ganing Yusnaeni. 2015. Korelasi Antara Keterampilan Metakognitif dengan Hasil Belajar Biologi Siswa SMP Negeri Kupang. JURNAL BIOLOGI SCIENCE \& EDUCATION. VOL.4. NO.1

Iskandar, Srini. 2014. Pendekatan Keterampilan Metakognitif Dalam Pembelajaran Sains Di Kelas. ERUDIO. Vol.2.No.2

Sihotang, Darpin, Tamin Ritonga dan Roslian Lubis. 2020. Analisis Keterampilan Metakognisi Siswa Dalam Menyelesaikan Soal Matematika Di Kelas XI SMK NEGERI 1 Sosorgadong. JURNAL Mathedu (Matematic Education Journal).vol.4.no.1

Supriatna, Ecep dan Tuti Alawiyah. 2019. Studi Keterampilan Metakognitif Pada Siswa Sekolah Menengah Atas Negeri (SMAN) 1 Margaasih Kabupaten Bandung. Jurnal Bimbingan, Penyuluhan, Konseling dan Psikoterapi Islam. Vol.7.No.4

Siregar Suriani. 2019. Analisis Keterampilan Metakognitif dan Sikap Ilmiah Siswa Melalui Metode Pembelajaran Inkuiri. Jurnal Biotik. Vol.7. No.2

Sugiyono. Metode Penelitian Pendidikan. Cetakan Ke 25. 2017. Bandung: Alfabeta

Sugiyono, 2014. Metode Penelitian Manajemen, Bandung: Alfabeta

Suharsini, Arikunto. Prosedur Penelitian. Cetakan 15. 2014 Jakarta: Rineka Cipta

Toraman, Cetin, dkk. 2020. Analysis Of The Relationships Between Mathematics Achievement, Reflective Thingking Of Problem Solving And Metacognitive Awareness. International Journal Of Progressive Education. Vol.16. No.2

Tachie Simon. 2019. Metacognitive skills and Strategis Application: How this Help Learners in Mathematics Problem-solving. EURASIA Journal of Mathematics. Vol.15. No.5 